Article

\title{
Health Risk Assessment in Agricultural Soil Potentially Contaminated by Geogenic Thallium: Influence of Plant Species on Metal Mobility in Soil-Plant System
}

\author{
Luigi Giuseppe Duri ${ }^{1,+}$, Donato Visconti ${ }^{1, *+\dagger}\left(\mathbb{D}\right.$, Nunzio Fiorentino ${ }^{1}$, Paola Adamo ${ }^{1,2}$, \\ Massimo Fagnano ${ }^{1}$ and Antonio Giandonato Caporale ${ }^{1}$ (D) \\ 1 Department of Agricultural Sciences, University of Naples Federico II, 80055 Portici, Italy \\ 2 Interdepartmental Research Centre on the 'Earth Critical Zone' for Supporting the Landscape and \\ Agroenvironment Management (CRISP), University of Naples Federico II, 80055 Portici, Italy \\ * Correspondence: donato.visconti@unina.it \\ + L.G.D. and D.V. contributed equally to this work.
}

Received: 17 May 2020; Accepted: 19 June 2020; Published: 23 June 2020

check for updates

\begin{abstract}
In agricultural soils, thallium (Tl) of geogenic origin may represent a potential risk for human health, mainly via ingestion of food crops. In this work, a pot experiment was carried out to evaluate (1) the bioavailability of $\mathrm{Tl}$ and other potentially toxic elements (PTEs) in an agricultural soil with naturally occurring Tl; (2) the uptake and accumulation of PTEs in Lactuca sativa L. var. acephala, Diplotaxis tenuifolia L. DC and Silene latifolia Poir; (3) the health risks arising from plant and soil ingestion by different subpopulations and dermal contact of soil by farmers. In soil, only $\mathrm{Tl}$ and $\mathrm{Pb}$ pseudototal contents were above Italian screening values. Nevertheless, the promptly bioavailable contents of all PTEs were always below internationally recognized trigger values. Plants affected PTE bioavailability in soil by their rhizodepositions and accumulated PTEs in their shoots. Acceptable risks (hazard index $<1$ ) arose from dietary intake of both L. sativa L., D. tenuifolia L. and dermal contact of soil by farmers. Significant health risks can derive from the intake of S. latifolia Poir. (accumulating high $\mathrm{Tl}$ concentrations), in particular by children $(\mathrm{HI}=74)$. In conclusion, an adequate management and crop selection are needed to profitably exploit soils with geogenic $\mathrm{Tl}$ for agricultural purposes.
\end{abstract}

Keywords: thallium; potentially toxic elements; bioavailability; bioaccumulation; hazard quotient and index; sanitary risk

\section{Introduction}

Thallium (Tl) is a nonessential and highly-toxic element for living organisms, generally showing a greater acute and chronic toxicity than other harmful elements, such as $\mathrm{As}, \mathrm{Cd}, \mathrm{Hg}$ and $\mathrm{Pb}[1,2]$. Serious Tl poisoning may lead to gastrointestinal dysfunction, ascending paralysis and mental disorders, whilst polyneuritis may occur with chronic poisoning [3-5]. The lethal dose of $\mathrm{Tl}$ for an adult human is only $8-10 \mathrm{mg} \mathrm{kg}^{-1}$; therefore, it is classified as one of the 13 priority metal pollutants by the United States Environmental Protection Agency and also listed in the European Union (EU) as a dangerous pollutant [6-8]. The main routes of human exposure to $\mathrm{Tl}$ are the ingestion of contaminated food and drinking water [9]. Once ingested, $\mathrm{Tl}$ quickly reaches the principal human organs and eventually accumulates in the nervous system [10].

Although $\mathrm{Tl}$ is a rare element, ranging from 0.1 to $2.0 \mathrm{mg} \mathrm{kg}^{-1}$ in terrestrial environments (average content of $0.5 \mathrm{mg} \mathrm{kg}^{-1}$ in the continental crust) [11,12], it can occur at higher extent in various sulphide 
minerals (e.g., sphalerite, galena, pyrite and chacopyrite) and in K-bearing silicates such as micas and feldspars [13], thus resembling the chemical behaviour of both chalcophile $(\mathrm{Cu}, \mathrm{Pb}, \mathrm{Zn})$ and lithophile

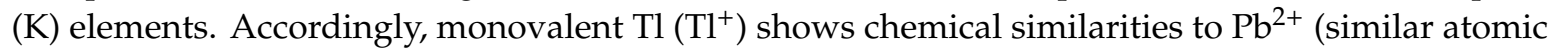
weight) and $\mathrm{K}^{+}$(similar radius). Since it can replace $\mathrm{K}^{+}$in the metabolic processes, $\mathrm{Tl}$ is highly toxic for the plants [14]. Thallium can form stable interactions with sulfhydryl and phosphate ligands of proteins, causing their inactivation [15].

In recent years, soil contamination by $\mathrm{Tl}$ has been reported in many countries worldwide, mainly due to industrial activities, such as mining/smelting of Tl-bearing sulphide deposits, burning fossil fuels and cement production [1]. The mobility and bioavailability of $\mathrm{Tl}$ in the soil depends on many factors, such as the nature of $\mathrm{Tl}$ sources, soil mineralogy, content and quality of soil organic matter (SOM), water precipitation and cycle and biological activity [16]. Unlike other PTEs such as As, Cd, Cr, $\mathrm{Hg}$ or $\mathrm{Pb}$, there is still a lack of information on the health risks arising from the exposure to $\mathrm{Tl}$ naturally occurring in the soil, which can be potentially transferred to pore water and thus to crop plants [8].

The understanding of the sources, extent and spatial distribution of potentially toxic elements (PTEs) such as $\mathrm{Tl}$ in the soil, and the study of possible contaminant transfer to food crops and farmers, are pivotal to properly manage the risks deriving from the cultivation of a contaminated farmland.

To assess the potential health risks due to the ingestion of crops produced in a contaminated soil, the worst case approach may be applied by growing plants able to tolerate or accumulate PTEs, such as lettuce (Lactuca sativa L. var. acephala), perennial wall rocket (Diplotaxis tenuifolia L. DC) and white campion (Silene latifolia Poir.) in pot trials under controlled conditions [17]. Lactuca sativa L. is a common crop plant showing a good capacity to accumulate $\mathrm{Pb}, \mathrm{Tl}$ and $\mathrm{Zn}$ in its own tissues $[18,19]$. D. tenuifolia L. DC is an edible native wild plant species in Italy [20], but is also cultivated in open fields or greenhouses [21], where it can be an effective biomonitor of soil contamination [22]. Silene latifolia Poir. is a native perennial wild plant species in Italy [20]. Leaves and young stems of this plant are consumed in many Mediterranean countries [23-25] where it can be boiled, fried, cooked to make soups or pasta and risotto dishes [26]. Silene latifolia Poir. can accumulate high concentrations of PTEs in its biomass, in particular $\mathrm{Tl}[27,28]$. To evaluate and compare the uptake and accumulation of PTEs in the shoots of these biomonitor plants, the bioaccumulation coefficient (BAC) is basically adopted as index relating the concentration of PTEs in plant shoots to that in the cultivation soil $[28,29]$.

A proper management of soil contamination leads to the minimisation of the ecological threat and the health risks due to exposure to soil contaminants [30]. The assessment of the pseudototal content of PTEs after aqua regia digestion can give insight on the extent and spatial variability of contamination, but it is not adequate to quantify the soluble and promptly bioavailable fractions of PTEs actually interacting with plant roots and soil microbiota in the highly dynamic rhizospheric environment [31,32]. Different single-step chemical extractions have been developed and standardised to estimate the promptly bioavailable fractions of PTEs in the soil, some of them are also officially recognised by many European countries to assess potential risks for growth and food safety of crops [33,34].

The present work aims at studying (1) the bioavailability of $\mathrm{Tl}$ and other PTEs occurring in an agricultural soil of south Italy and mainly originating from the volcanic activity of the Somma-Vesuvius complex; (2) the influence of plant species (Lactuca sativa L. var. acephala, Diplotaxis tenuifolia L. DC and Silene latifolia Poir.) on the mobility of PTEs in the soil and their assimilation in plant tissues; (3) the health risks for different subpopulations potentially consuming edible plants grown on the studied soil and farmers working and exploiting the site for agricultural purposes.

\section{Materials and Methods}

\subsection{Geological Features of the Study Area and Soil Sampling on Field}

An agricultural soil was collected from a farmland of $35,000 \mathrm{~m}^{2}$, sited in a rural area of the Afragola municipality (Naples, Campania, Italy). Eight discrete samples were collected on a grid $(40 \times 40 \mathrm{~m})$ in 
the $0-20 \mathrm{~cm}$ soil layer (Figure S1) and then mixed thoroughly to form a composite sample which was successively used for the pot experiment with three plant species.

A portion of discrete samples and composite sample was dried at $50{ }^{\circ} \mathrm{C}$ until constant weight, homogenized and sieved at $2 \mathrm{~mm}$, in order to evaluate the main physicochemical properties.

The study area is in the Piana Campana graben, to the NW of the Somma-Vesuvius complex and NE of the Phlegrean Fields (Figure S1), the main active volcanoes of Campania. In this volcanic area, there was an accumulation of pyroclastic deposits [35]. Therefore, the soils of this territory are the result of a different extent of andosolization, which produced soils that can be classified as Pachi-Vitric Andosols and Hypereutric Cambisols [36,37].

\subsection{Experimental Setup}

The pot experiment was carried out in an unheated polyethylene greenhouse sited at the Department of Agricultural Sciences, University of Naples Federico II, southern Italy $\left(40^{\circ} 49^{\prime} \mathrm{N}\right.$, $14^{\circ} 15^{\prime} \mathrm{E}$ ). Seeds of lettuce (Lactuca sativa L. var. acephala) and perennial wall rocket (Diplotaxis tenuifolia L. DC) where bought from a local supplier, while white campion seeds (Silene latifolia Poir.) were collected in 2017 from spontaneous plants growing near the roads or in open fields of the Parco Gussone (Department of Agricultural Sciences, University of Naples Federico II, southern Italy). Then, seeds were surface-sterilized before storing by immersion in $5 \%(\mathrm{~V} / \mathrm{V})$ sodium hypochlorite for $10 \mathrm{~min}$ and washed three times in sterile water [38]. Soil from the composite sample was transferred to pots (four replicates per plant species; $\varnothing 16 \mathrm{~cm} ; \mathrm{V} 2 \mathrm{~L})$. Then, seeds of white campion $(0.4 \mathrm{~g}$ per pot), lettuce $(0.2 \mathrm{~g}$ per pot) and perennial wall rocket $(0.1 \mathrm{~g}$ per pot) were sown at the end of October 2018 in the pots (Figure S1). White campion and lettuce were then thinned to five plants per pot after germination. Pots were watered regularly to keep soil moisture close to field capacity and all plants were harvested three times in the same pot (from March to June 2019) during the experiment that lasted for a total of 33 weeks.

\subsection{Plant Sampling, Processing and Analysis}

Each harvest of shoot biomass was carried out when stem length was at least $15 \mathrm{~cm}$. All the fresh shoot samples were thoroughly washed with tap water and then deionized water, gently blotted, weighed (fresh weight), oven-dried at $60{ }^{\circ} \mathrm{C}$ to constant dry weight and, later, finely ground in an electric mill. Shoot dried samples were firstly digested by concentrated $\mathrm{HNO}_{3}$ and secondly by aqua regia in a microwave oven, then the concentration of PTEs in the extracts were detected by inductively coupled plasma mass spectrometry (ICP-MS) (analytical package VG101-EXT) at Acme Analytical Laboratories Ltd. (Vancouver, Canada) within a time span of 25 days from receiving the samples to final delivery of analytical results. Certified reference material (oriental tobacco leaves CTA-OTL-1) and lab standard materials (STD CDV-1 and STD V16) were used to monitor the data quality of analyses, with metal recoveries around $\pm 8 \%$ of the certified values. PTE concentrations in the plants were compared to PTE thresholds indicated in EC Reg. 1881/2006 for vegetables (Cd: $0.2 \mathrm{mg} \mathrm{kg}^{-1}$ f.w.; Pb: $0.3 \mathrm{mg} \mathrm{kg}^{-1}$ f.w.) [39]. In addition, the range values of PTEs found in food plants growing on nonpolluted sites (Cd: $0.029-0.4 \mathrm{mg} \mathrm{kg}^{-1}$ d.w.; $\mathrm{Cu}$ : 6-8 $\mathrm{mg} \mathrm{kg}^{-1}$ d.w.; Pb: $0.7-3.6 \mathrm{mg} \mathrm{kg}^{-1}$ d.w.; Tl: $0.02-0.125 \mathrm{~kg}^{-1}$ d.w.; $\mathrm{Zn:} 44-73 \mathrm{~kg}^{-1}$ d.w.) by Kabata-Pendias, [12], were used as reference values.

To evaluate the accumulation of PTEs, the bioaccumulation coefficient (BAC) was calculated as follows:

$$
\mathrm{BAC}=\frac{\mathrm{C}_{\text {shoots }}}{\mathrm{C}_{\text {soil }}}
$$

where $\mathrm{C}_{\text {shoots }}$ and $\mathrm{C}_{\text {soil }}$ are the PTE concentrations $\left(\mathrm{mg} \mathrm{kg}^{-1}\right)$ in shoots and soil, respectively [28,29].

\subsection{Soil Sampling at Pot Scale and Physicochemical Characterization}

At the end of the experiment, the soils in the pots were dried at $50{ }^{\circ} \mathrm{C}$ until constant weight, homogenized and sieved at $2 \mathrm{~mm}$ before analysis. Afterwards, all the sieved and dried soil samples 
(before and after plant cultivation) were characterized for the following physicochemical properties: $\mathrm{pH}-\mathrm{H}_{2} \mathrm{O}$ (1:2.5 soil:water solution ratio, $\mathrm{pH}$ meter GLP 22, Crison), electrical conductivity (1:5 soil:water solution ratio, Conductimeter basic 30, Crison), organic carbon [40], extraction of promptly bioavailable fraction of PTEs by ammonium nitrate (described in the Section 2.4.2).

In the discrete and composite soil samples collected before plant cultivation, the texture (pipette and sieving method, after pretreatment with $\mathrm{H}_{2} \mathrm{O}_{2}$ to oxidize organic matter and particle dispersion by sodium hexametaphosphate), total nitrogen (Kjeldahl method), available phosphorous (Olsen method), exchangeable potassium (extraction with $0.5 \mathrm{M}$ ammonium acetate and potassium evaluation by spectrophotometer) and pseudototal content of PTEs (described in the Section 2.4.1) were also determined.

\subsubsection{Determination of Pseudototal Content of PTEs}

Pseudototal PTE contents were quantified in $1 \mathrm{~g}$ of each pulverized soil sample by aqua regia digestion [41] and ICP-MS at Acme Analytical Laboratories Ltd. (Vancouver, Canada), within a time span of 25 days from receiving the samples to final delivery of analytical results. Certified reference material ERM-CC141 Loam Soil and BCR-141R Calcareous Loam Soil (European Reference Materials, ERM $^{\circledR}$ ) and lab standard materials (STD DS10 and STD OREAS45EA) were used to monitor the data quality of soil analyses, with metal recoveries around $\pm 10 \%$ of the certified values.

\subsubsection{Extraction of Promptly Bioavailable Fraction of Metals by Ammonium Nitrate}

Ten grams of $2 \mathrm{~mm}$-sieved soil were extracted with $25 \mathrm{~mL}$ of $1 \mathrm{M} \mathrm{NH}_{4} \mathrm{NO}_{3}$ solution $(\mathrm{m} / \mathrm{V}=1: 2.5)$ into a $50 \mathrm{~mL}$ FalconTM tube, by shaking for $120 \mathrm{~min}$ at $20 \pm 2{ }^{\circ} \mathrm{C}$ with a horizontal shaker [42]. The extract was separated from the solid residue by centrifugation at $1000 \times g$ for $10 \mathrm{~min}$ and the supernatant was filtered by $25 \mathrm{~mL}$ syringe equipped with a $0.45 \mu \mathrm{m}$ disposable in-line membrane filter, acidified by $65 \% \mathrm{HNO}_{3}$ (final acid concentration: $1 \%$ ) and then stored at $4{ }^{\circ} \mathrm{C}$ in a refrigerator prior to being analysed. The promptly bioavailable metal contents in the filtrates were measured by ICP-MS at Acme Analytical Laboratories Ltd. (Vancouver, BC, Canada) within a time span of 25 days from receiving the samples to final delivery of analytical results. The detection limits of $\mathrm{Cd}, \mathrm{Cu}, \mathrm{Pb}, \mathrm{Tl}$ and Zn were respectively $0.005,0.010,0.020,0.001$ and $0.025 \mathrm{mg} \mathrm{kg}^{-1}$.

\subsection{Health Risk Assessment}

PTEs may cause both carcinogenic and noncarcinogenic risks through different pathways. According to Italian law, the main risk for human health in agricultural lands is through crop ingestion [43]; however, agricultural workers' exposure through ingestion and dermal contact of soil were evaluated in a health risk assessment [44]. The noncarcinogenic risks were assessed by calculating the hazard quotient (HQ) for each exposure pathway and each PTE [17,45,46]:

$$
\mathrm{HQ}=\frac{\mathrm{ADD}}{\mathrm{RfD}}
$$

where ADD is the average daily dose $\left(\mathrm{mg} \mathrm{kg}^{-1} \mathrm{day}^{-1}\right)$ and RfD is the chronic reference dose of each PTE (mg kg-1 day ${ }^{-1}$ ). Oral reference dose (RfDo) values used in the dietary and soil ingestion health risk assessment are shown in Table S1 [47].

Reference dose for dermal absorption (RfDd) was calculated for each PTE from oral reference dose using equation [48]:

$$
\mathrm{RfDd}=\frac{\mathrm{RfDo}}{\mathrm{ABS}_{\mathrm{GI}}}
$$

where RfDd is the adjusted reference dose for dermal exposure $\left(\mathrm{mg} \mathrm{kg}^{-1} \mathrm{day}^{-1}\right)$ and $\mathrm{ABS}_{\mathrm{GI}}$ is the gastrointestinal absorption factor (dimensionless). 
The cumulative risk of all PTEs for each exposure pathway was evaluated by calculating the Hazard Index (HI) by using the equation:

$$
\mathrm{HI}=\sum \mathrm{HQ}
$$

HQ or HI values $>1$ indicate significant risk to human health [45,46].

The ADD was calculated for the dietary intake ( $\left.\mathrm{ADD}_{\text {dietary }}\right)$ for different age groups (children, 3-9 years; adolescents, 10-17 years; adults, 18-64 years; elderly, 65-74 years) while ADDs for soil ingestion $\left(\mathrm{ADD}_{\mathrm{ing}}\right)$ and dermal contact with soil $\left(\mathrm{ADD}_{\text {dermal }}\right)$ were assessed for adult farm workers as follows $[43,45,49,50]$ :

$$
\begin{gathered}
\mathrm{ADD}_{\text {dietary }}=\mathrm{C}_{\text {plant }} \times \frac{\mathrm{IngR} \mathrm{R}_{\text {plant }} \times \mathrm{EF} \times \mathrm{ED}}{\mathrm{BW} \times \mathrm{AT}} \\
\mathrm{ADD}_{\text {ing }}=\mathrm{C}_{\text {soil }} \times \frac{\mathrm{IngR}_{\text {soil }} \times \mathrm{EF} \times \mathrm{ED}}{\mathrm{BW} \times \mathrm{AT}} \times 10^{-6} \\
\mathrm{ADD}_{\text {dermal }}=\mathrm{C}_{\text {soil }} \times \frac{\mathrm{SA} \times \mathrm{AF} \times \mathrm{ABS} \times \mathrm{EF} \times \mathrm{ED}}{\mathrm{BW} \times \mathrm{AT}} \times 10^{-6}
\end{gathered}
$$

where:

- $\quad \mathrm{C}_{\text {plant }}\left(\mathrm{mg} \mathrm{g}^{-1}\right)$ and $\mathrm{C}_{\text {soil }}\left(\mathrm{mg} \mathrm{kg}^{-1}\right)$ are the PTEs concentrations in plants and soil, respectively. For each plant, max PTE concentrations found in the shoot at the three harvests were used in this study;

- $\quad \operatorname{IngR}_{\text {plant }}\left(\mathrm{g} \mathrm{day}^{-1}\right)$ and $\operatorname{IngR} R_{\text {soil }}\left(\mathrm{mg} \mathrm{day}^{-1}\right)$ are the plants and soil ingestion rate per day, respectively;

- $\quad \mathrm{SA}$ is the exposed skin surface area $\left(\mathrm{cm}^{2}\right)$;

- $\mathrm{AF}$ is the skin adherence factor $\left(\mathrm{mg} \mathrm{cm}^{-2}\right.$ day $\left.^{-1}\right)$;

- $\mathrm{ABS}$ is the dermal absorption factor (dimensionless);

- $\quad \mathrm{EF}$ is the exposure frequency (day year $\left.{ }^{-1}\right)$;

- $\quad \mathrm{ED}$ is the exposure duration (years);

- $\quad$ BW is the body weight $(\mathrm{kg})$;

- $\quad$ AT is the period over witch exposure is averaged (days). For non-carcinogenic risk assessment $\mathrm{AT}=\mathrm{ED} \times 365$ days while for carcinogenic risk assessment $\mathrm{AT}=70 \times 365$ assuming that carcinogenic effects may occur also when exposure ends.

Carcinogenic risks were evaluated by equation:

$$
\mathrm{CR}=\mathrm{ADD} \times \mathrm{SF}
$$

where $\mathrm{CR}$ is the cancer risk (dimensionless) and $\mathrm{SF}$ is the cancer slope factor $\left(\mathrm{mg} \mathrm{kg}^{-1} \mathrm{day}^{-1}\right)^{-1}$. Oral slope factor (SFo) values are shown in Table S1 [47], while the dermal slope factor (SFd) was evaluated by the following equation [48]:

$$
\mathrm{SFd}=\frac{\mathrm{SFo}}{\mathrm{ABS}_{\mathrm{GI}}}
$$

where SFd is the dermal slope factor, $\mathrm{SFo}$ is the oral slope factor and $\mathrm{ABS}_{\mathrm{GI}}$ is the gastrointestinal absorption factor (dimensionless).

The acceptable or tolerable risk is within the range of $1 \times 10^{-6}-1 \times 10^{-4}$ and values lower than $1 \times 10^{-6}$ are considered negligible. Carcinogenic risk values higher than $1 \times 10^{-4}$ are likely to be harmful to humans [51].

All the parameters used in the health risk assessment equations are shown in Tables S2 and S3. 


\subsection{Statistical Analysis}

All data were subjected to analysis of variance (ANOVA) via a general linear model and mean values were separated according to a least significant difference (LSD) test with $p<0.05$, using the software IBM SPSS Statistics 25. The Kolmogorov-Smirnov and Levene tests were used to verify normality of distribution and homogeneity of variance, respectively. Logarithmic transformation was applied, when needed, to variables that did not accomplish normality. Pearson correlation analysis was carried out between soil and plant PTE concentrations by XLStat (Addinsoft, Paris, France) to evaluate general tendencies.

\section{Results and Discussion}

\subsection{Soil Physicochemical Properties, Pseudototal and Promptly Bioavailable Contents of PTEs}

The main physicochemical properties and pseudototal content of PTEs of the composite soil sample used in the pot experiment, obtained by mixing discrete soil samples collected from the agricultural soil, are reported in Table 1.

The soil was sandy loam and showed a slightly acid to subneutral $\mathrm{pH}$ (6.43), which made the bioavailability of the main nutrients such as phosphate optimal for plant growth. The electrical conductivity was quite low, hence there was no accumulation of soluble salts which could potentially inhibit plant growth. The soil showed a medium-low content in organic matter (OM), typical of soils exploited for agricultural purposes in Mediterranean countries. The content in total $\mathrm{N}$ was moderate, in a good equilibrium with the organic $C$ content; the $C / N$ ratio was 9.57 , a value which indicated that the primary inputs of organic matter from crop residues were properly mineralised by soil microbiota. The medium-high availability of $\mathrm{P}$ and the good cation exchange capacity (CEC) adequately saturated by exchangeable $\mathrm{K}$ revealed a good soil chemical fertility and availability of the major plant nutrients. The good fertility of the volcanic soils of metropolitan area of Naples was also highlighted in other studies [36,37].

The pseudototal contents of $\mathrm{Cd}, \mathrm{Cu}$ and $\mathrm{Zn}$ were below the screening values set by the Italian Ministerial Decree 46 for agricultural soils [43], but also lower than the baseline values of volcanic soils in the metropolitan area of Naples proposed by Cicchella et al. [52] and De Vivo et al. [53]. These findings can be observed in all the eight discrete samples collected from the agricultural soil (Table S4) and, as a consequence, in the composite soil sample used in the pot experiment (Table 1). On the other hand, the pseudototal content of $\mathrm{Tl}$ was twofold higher (Table 1 and Table S4) than the screening value for agricultural soils $\left(1 \mathrm{mg} \mathrm{kg}^{-1}\right.$, [43]); however, it was within the range of $\mathrm{Tl}$ baseline values (1.7-2.7 $\mathrm{mg} \mathrm{kg}^{-1}$ ) found by Cicchella et al. [52] and De Vivo et al. [53] in the volcanic soils originating from the Somma-Vesuvius complex. Therefore, according to these comprehensive geological studies, the $\mathrm{Tl}$ content in the studied farmland should be basically of geogenic nature. Similarly, the pseudototal content of $\mathrm{Pb}$ exceeded of $\sim 20 \%$ the screening value for agricultural soils (100 $\mathrm{mg} \mathrm{kg}^{-1}$, [43]), but it was within the medium-high baseline values of the metropolitan area of Naples [52,53], due to both geogenic factors (e.g., hydrothermal fluids related to Vesuvius fractures) and anthropogenic contribution (fall-out and accumulation of $\mathrm{Pb}$ from tetraethyl lead, added to gasoline as an anti-knock agent until the 1990s).

The bioavailable content of PTEs in the soil, along with $\mathrm{pH}$, EC and OC measures, before (T0) and after the growing cycle of lettuce (T1-L), perennial wall rocket (T1-R) and white campion (T1-S) plants, are shown in Table 2. 
Table 1. Physicochemical properties of the composite soil sample used in the pot experiment before plant sowing (time T0).

\begin{tabular}{|c|c|c|c|c|c|c|c|c|c|c|}
\hline \multirow{6}{*}{ Soil } & Sand & Silt & Clay & $\mathrm{pH}$ & EC & CEC & OC & OM & TN & $\mathrm{C} / \mathrm{N}$ \\
\hline & & $\mathrm{g} \mathrm{kg}^{-1}$ & & & $\mathrm{dS} \mathrm{m}^{-1}$ & $\mathrm{cmol}(+) \mathrm{kg}^{-1}$ & & $\mathrm{~g} \mathrm{~kg}^{-1}$ & & \\
\hline & $554 \pm 24$ & $249 \pm 13$ & $197 \pm 9$ & $6.43 \pm 0.02$ & $0.15 \pm 0.01$ & $27.1 \pm 0.2$ & $15.5 \pm 0.2$ & $26.7 \pm 0.4$ & $1.6 \pm 0.1$ & 9.6 \\
\hline & \multicolumn{5}{|c|}{ Pseudo-total } & & & & & \\
\hline & $\mathrm{Cd}$ & $\mathrm{Cu}$ & $\mathrm{Pb}$ & $\mathrm{Tl}$ & $\mathrm{Zn}$ & AP & EK & & & \\
\hline & & & $\mathrm{mg} \mathrm{kg}^{-1}$ & & & & & & & \\
\hline Soil & $0.29 \pm 0.02$ & $116 \pm 4$ & $117 \pm 12$ & $2.0 \pm 0.1$ & $127 \pm 4$ & $0.10 \pm 0.01$ & $1.60 \pm 0.01$ & & & \\
\hline $\mathrm{SV}^{\mathrm{a}}$ & 5 & 200 & 100 & 1.0 & 300 & - & - & & & \\
\hline $\mathrm{BV}^{\mathrm{b}}$ & 0.50 & 163 & 100 & 1.5 & 142 & - & - & & & \\
\hline
\end{tabular}

a Screening values (SV) of Italian Ministerial Decree 46 [43]. ${ }^{\text {b }}$ Baseline values (BV) of Neapolitan volcanic soils [52]. In bold values above the Italian screening values or baseline values of Neapolitan volcanic soils. EC: electrical conductivity; CEC: cation exchange capacity; OC: organic carbon, OM: organic matter; TN: total nitrogen; C/N: carbon-to-nitrogen ratio; AP: available phosphorus; EK: exchangeable potassium. Values (mean \pm standard error).

Table 2. $\mathrm{pH}$, electric conductivity (EC), organic $\mathrm{C}(\mathrm{TOC})$ and $\mathrm{NH}_{4} \mathrm{NO}_{3}$-extractable $\mathrm{Cd}, \mathrm{Cu}, \mathrm{Pb}$, $\mathrm{Tl}$ and $\mathrm{Zn}$ in soil before plant sowing (T0) and at the end of the experiment (T1).

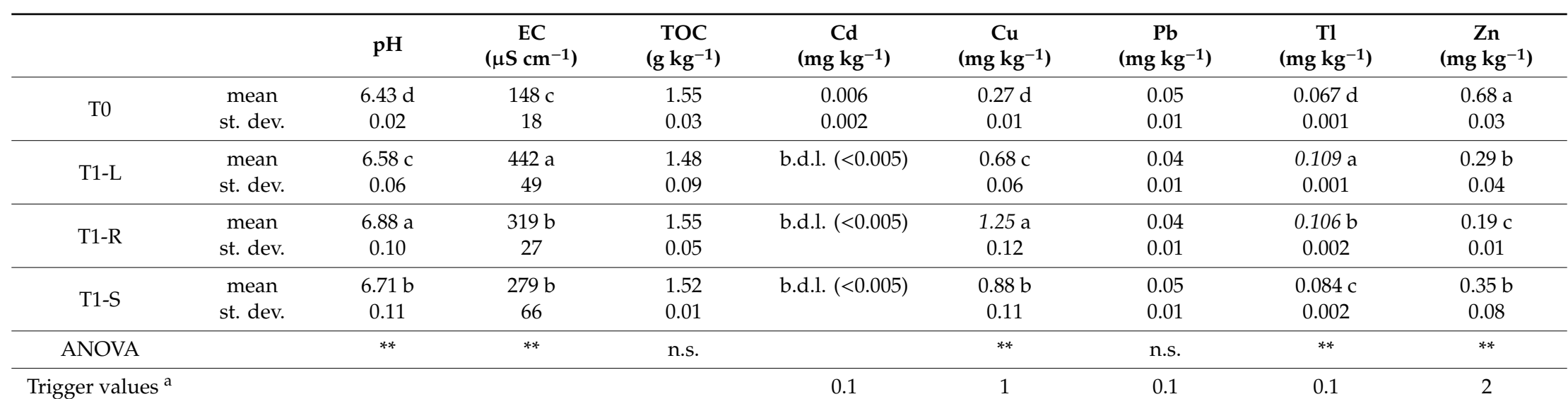

$\mathrm{L}$, lettuce; R, perennial wall rocket; S, S. latifolia. Values followed by the same letter do not differ significantly according to the LSD test $(p<0.05)$. b.d.l., below detection limit. ***: $p<0.05$ and 0.01 , respectively; n.s., not significant. ${ }^{\text {a }}$ Trigger values settled by Germany [33] and Slovak Republic [34] to indicate a potential risk for the soil-food-plant pollutant transition in agricultural areas and in vegetable gardens with regard to the plant quality. In italic-values above the reference trigger values. 
After plant growing cycles, we found a statistically significant increase of both soil $\mathrm{pH}$ and EC values, probably due to the enhanced biological activity triggered by the release of rhizodepositions by plant roots. Nevertheless, the content in organic $\mathrm{C}$ after plant growing cycles did not showed statistically significant differences in comparison to the initial medium-low content.

The promptly bioavailable fractions of all the PTEs in the soil before plant growth were lower than the trigger values settled by Germany and Slovak Republic to indicate a potential risk for growth and food safety of crops (Table 2) $[33,34,54]$. This means that all the PTEs are basically poorly bioavailable in the soil, even those showing pseudototal contents higher than screening values for agricultural soils [43], such as $\mathrm{Tl}$ (the most concerning metal in the site) and $\mathrm{Pb}$. In terms of percentage, the promptly bioavailable fractions of $\mathrm{Cd}, \mathrm{Cu}, \mathrm{Pb}, \mathrm{Tl}$ and $\mathrm{Zn}$ were the $2.1,0.2,<0.1,3.4$ and $0.5 \%$, respectively, of the pseudototal contents. These outcomes can be justified by the presumed geogenic nature of all the PTEs in the soil [52,53], which can be likely occluded or interlayered in the soil mineral lattice. Additionally, the soil physicochemical properties and the subneutral $\mathrm{pH}$ may contribute to minimise the solubility and bioavailability of PTEs in the soil, which tends to precipitate as metal (hydr)oxides or form stable and sparingly soluble organomineral complexes [31,55].

The promptly bioavailable contents of $\mathrm{Cu}$ and $\mathrm{Tl}$ in the soil increased after plant growing cycles, whereas the opposite was observed for $\mathrm{Zn}$ bioavailable fraction (Table 2). A significant reduction of bioavailable Zn (from 43 to 92\%) was also observed by Rocco et al. [56] in two soils potentially polluted by $\mathrm{Cu}$ and $\mathrm{Zn}$ of Campania (southern Italy), after one year of phytoremediation with Eucalyptus camedulensis L. and Populus nigra L. The increased bioavailability of $\mathrm{Tl}$ after plant growth might be related to the enhanced bioavailability of $\mathrm{K}$ triggered by rhizodepositions and soil microbiota at the soil-root interface, since the geochemistry of two elements in the soil is very similar [57]. Moreover, since $\mathrm{Tl}$ seems not to be strongly complexed by humic acids in soils [58], in the OM-rich rhizospheric soil, Tl can move from soil to pore waters and thus become bioavailable to plants [8,59]. No statistically significant variation from the start point was found for bioavailable $\mathrm{Pb}$ after plant growing cycles, as well as for bioavailable $\mathrm{Cd}$ whose concentrations after plant growth were below the instrumental detection limit $\left(0.005 \mathrm{mg} \mathrm{kg}^{-1}\right)$. The perennial wall rocket was able to rise 4.6 -fold the initial $\mathrm{Cu}$ bioavailable fraction after three harvest cycles, but also white campion and lettuce plants produced a significant increase of bioavailable $\mathrm{Cu}$ (3.3-fold and 2.5-fold higher than the start point, respectively). This enhanced $\mathrm{Cu}$ bioavailability after plant growth may be due to the strong affinity of the metal for dissolved organic matter (DOM). Rhizodepositions and the consequent increase in microbial activity usually contribute to raise the concentration of DOM in the rhizospheric soil which often leads to a concomitant increase of $\mathrm{Cu}$ promptly bioavailable content [60]. Likewise, the promptly bioavailable content of $\mathrm{Tl}$ was raised of $57 \%$ after three harvest cycles of lettuce and perennial wall rocket and of $14 \%$ after three harvest cycles of white campion. On the other hand, the initial bioavailable content of $\mathrm{Zn}$ was lowered 49,57 and $72 \%$ by white campion, lettuce and perennial wall rocket plants, respectively.

\subsection{Plant Biomass and PTE Uptake in Relation to Soil Promptly Bioavailable Contents}

The dried biomass and PTE concentrations in shoots of the three plant species, at the first, second and third harvests, are shown in Table 3.

The dried biomass of the three plants was not significantly different between the first and second harvests, while a reduction of $51 \%$ for lettuce and of $37 \%$ for white campion at the third harvest occurred in comparison to the second harvest (Table 3). Lettuce requires a sufficient supply of essential macronutrients (particularly nitrogen) generally by mineral fertilizers, which can be integrated with plant biostimulants $[61,62]$. Consequently, the biomass reduction showed by lettuce was probably related to low agronomical inputs. In contrast, perennial wall rocket showed no biomass reduction at the third harvest, showing a good adaptability to continuous harvests, as observed by Caruso et al. [21] reporting a stable biomass production up to five consecutive harvests. 
Table 3. Plant biomass (g d.w.) and concentration of PTEs ( $\mathrm{mg} \mathrm{kg}^{-1}$ d.w.) in shoots of L. sativa, D. tenuifolia and S. latifolia at the first, second and third harvests.

\begin{tabular}{|c|c|c|c|c|c|c|c|}
\hline & & $\begin{array}{c}\text { DW } \\
\left(\mathrm{g} \mathrm{pot}^{-1}\right)\end{array}$ & $\begin{array}{c}\mathrm{Cd} \\
\left(\mathrm{mg} \mathrm{kg}{ }^{-1}\right)\end{array}$ & $\begin{array}{c}\mathrm{Cu} \\
\left(\mathrm{mg} \mathrm{kg}^{-1}\right)\end{array}$ & $\begin{array}{c}\mathrm{Pb} \\
\left(\mathrm{mg} \mathrm{kg}^{-1}\right)\end{array}$ & $\begin{array}{c}\mathrm{Tl} \\
\left(\mathrm{mg} \mathrm{kg}^{-1}\right)\end{array}$ & $\begin{array}{c}\mathrm{Zn} \\
\left(\mathrm{mg} \mathrm{kg}^{-1}\right)\end{array}$ \\
\hline \multirow{4}{*}{ L. sativa } & $1^{\text {st }}$ harvest & $4.34 \mathrm{a}$ & $0.51 \mathrm{~b}$ & $14 \mathrm{~b}$ & $0.82 \mathrm{a}$ & 0.10 & $58 \mathrm{~b}$ \\
\hline & $2^{\text {nd }}$ harvest & $4.11 \mathrm{a}$ & $0.46 \mathrm{~b}$ & $8 \mathrm{~b}$ & $0.36 \mathrm{~b}$ & 0.09 & $51 \mathrm{~b}$ \\
\hline & $3^{\text {rd }}$ harvest & $2.08 \mathrm{~b}$ & $0.68 \mathrm{a}$ & $24 \mathrm{a}$ & $0.99 \mathrm{a}$ & 0.10 & $75 \mathrm{a}$ \\
\hline & ANOVA & $* *$ & $* *$ & $* *$ & $* *$ & n.s. & $* *$ \\
\hline \multirow{4}{*}{$\begin{array}{c}D . \\
\text { tenuifolia }\end{array}$} & $1^{\text {st }}$ harvest & 6.02 & $0.13 \mathrm{~b}$ & $7 \mathrm{~b}$ & 0.43 & $0.06 \mathrm{~b}$ & $40 \mathrm{~b}$ \\
\hline & $2^{\text {nd }}$ harvest & 6.45 & $0.31 \mathrm{a}$ & $24 \mathrm{a}$ & 0.49 & $0.23 \mathrm{a}$ & $56 \mathrm{a}$ \\
\hline & $3^{\text {rd }}$ harvest & 5.49 & $0.43 \mathrm{a}$ & $25 \mathrm{a}$ & 0.79 & $0.23 \mathrm{a}$ & $60 \mathrm{a}$ \\
\hline & ANOVA & n.s. & $* *$ & $* *$ & n.s. & $* *$ & $*$ \\
\hline \multirow{4}{*}{ S. latifolia } & $1^{\text {st }}$ harvest & $13.73 \mathrm{a}$ & $0.30 \mathrm{~b}$ & $6 c$ & $0.45 \mathrm{~b}$ & $7.66 \mathrm{a}$ & $21 b$ \\
\hline & $2^{\text {nd }}$ harvest & $6.69 \mathrm{~b}$ & $0.95 \mathrm{a}$ & $16 \mathrm{~b}$ & $0.45 \mathrm{~b}$ & $4.44 \mathrm{~b}$ & $47 \mathrm{a}$ \\
\hline & $3^{\text {rd }}$ harvest & $2.45 \mathrm{c}$ & $1.11 \mathrm{a}$ & $48 \mathrm{a}$ & $1.60 \mathrm{a}$ & $4.17 \mathrm{~b}$ & $49 a$ \\
\hline & ANOVA & $* *$ & $* *$ & $* *$ & $* *$ & * & $* *$ \\
\hline
\end{tabular}

Mean values with the same letter do not differ according to the least significant difference (LSD) test $(p<0.05)$. ${ }^{*} p<0.05 ;{ }^{* *} p<0.01 ;$ n.s., not significant.

Cadmium concentration in all plant shoots (Table 3) were above the reference ranges observed in food plants grown in nonpolluted sites [12], despite the low bioavailability of $\mathrm{Cd}$ in soil (Table 2). White campion also showed $\mathrm{Cd}$ concentration (fresh weight) higher than the threshold for vegetables at the third harvest (Table S5-[39]), suggesting a potential risk for human health linked to the ingestion of this plant. On average, lettuce and white campion showed the highest $\mathrm{Cd}$ concentration, twofold higher than perennial wall rocket (Table 4).

Table 4. Concentration of potentially toxic elements (PTEs) $\left(\mathrm{mg} \mathrm{kg}^{-1} \mathrm{~d}\right.$. w.) in shoots of L. sativa, D. tenuifolia and S. latifolia (three harvests weighted average).

\begin{tabular}{cccccc}
\hline & $\begin{array}{c}\mathbf{C d} \\
\left(\mathbf{m g ~ k g}^{-\mathbf{1}}\right)\end{array}$ & $\begin{array}{c}\mathbf{C u} \\
\left(\mathbf{m g ~ k g}^{-\mathbf{1}}\right)\end{array}$ & $\begin{array}{c}\mathbf{P b} \\
\left(\mathbf{m g ~ k g}^{-\mathbf{1}}\right)\end{array}$ & $\begin{array}{c}\mathbf{T l} \\
\left(\mathbf{m g ~ k g}^{-\mathbf{1}}\right)\end{array}$ & $\begin{array}{c}\mathbf{Z n} \\
\left(\mathbf{m g ~ k g}^{-\mathbf{1}}\right)\end{array}$ \\
\hline L. sativa & $0.52 \mathrm{a}$ & $13.4 \mathrm{~b}$ & 0.66 & $0.09 \mathrm{~b}$ & $58.8 \mathrm{a}$ \\
D. tenuifolia & $0.28 \mathrm{~b}$ & $18.6 \mathrm{a}$ & 0.57 & $0.17 \mathrm{~b}$ & $51.8 \mathrm{a}$ \\
S. latifolia & $0.57 \mathrm{a}$ & $13.7 \mathrm{~b}$ & 0.57 & $6.35 \mathrm{a}$ & $31.1 \mathrm{~b}$ \\
ANOVA & $* *$ & $* *$ & n.s. & $* *$ & $* *$ \\
\hline
\end{tabular}

Mean values with the same letter do not differ according to the LSD test $(p<0.05) .{ }^{*} p<0.05 ;{ }^{* *} p<0.01$; n.s., not significant.

The BAF of Cd was higher than other PTEs in most of the studied plants (Table 5), indicating its high mobility in the soil and transfer into plant tissues [50]. Furthermore, lettuce and white campion showed a BAF above unity (Table 5), thus suggesting a high $\mathrm{Cd}$ accumulation ability of the two crops in the studied soils [63]. Leafy vegetables such as lettuce showed a high tendency to accumulate $\mathrm{Cd}$ in previous studies [64,65], while white campion reported high Cd accumulation in polluted soils [28].

Table 5. Bioaccumulation factor (BAF) of each PTE in shoots of L. sativa, D. tenuifolia and S. latifolia (three harvests weighted average).

\begin{tabular}{cccccc}
\hline & \multicolumn{5}{c}{ BAF } \\
\hline & $\mathbf{C d}$ & $\mathbf{C u}$ & $\mathbf{P b}$ & $\mathbf{T 1}$ & $\mathbf{Z n}$ \\
\hline L. sativa & $\mathbf{1 . 8 3}$ & 0.11 & 0.006 & 0.05 & 0.46 \\
D. tenuifolia & 0.98 & 0.16 & 0.005 & 0.09 & 0.41 \\
S. latifolia & $\mathbf{1 . 9 8}$ & 0.12 & 0.005 & $\mathbf{3 . 2 6}$ & 0.24 \\
\hline
\end{tabular}


Copper concentration in plant tissues was higher than reference ranges measured in food plants grown on nonpolluted sites (Table 3-[12]). Additionally, perennial wall rocket showed the highest $\mathrm{Cu}$ concentration in shoots as compared to the other studied plants (Table 4), in accordance to the high bioavailable $\mathrm{Cu}$ content measured in the cultivation soil after plant growing cycles (above the trigger value settled by Germany and Slovak Republic; Table $2[33,34,54])$. Cu is a micronutrient for plants and this can justify, at least in part, the high $\mathrm{Cu}$ concentration in plant shoots. Indeed, many studied demonstrated as root exudates are able to mobilise $\mathrm{Cu}$ in the soil $[66,67]$.

Lead concentration in plant shoots (ranging from 0.57 to $0.66 \mathrm{mg} \mathrm{kg}^{-1}$ ) was below the reference ranges proposed by Kabata-Pendias [12] for food plants (Table 3; Table 4). The low concentration in plants and the low mobility of this PTE in soil (Table 2) suggested a low risk of Pb transfer into the food chain. However, white campion showed $\mathrm{Pb}$ concentration in shoots (fresh weight) higher than the threshold for vegetables at the third harvest (Table S5-[39]), suggesting a potential risk for human health linked to the ingestion of this plant.

Thallium concentration in perennial wall rocket and white campion was higher than reference ranges proposed by Kabata-Pendias [12] for food plants. This result was consistent with the high bioavailable $\mathrm{Tl}$ content in the soil, above the threshold for food safety (Table 2-[33,34,54]). D'Orazio et al. [8] reported that plants belonging to Brassicacea family as perennial wall rocket may accumulate high concentrations of $\mathrm{Tl}$. On the other hand, the low $\mathrm{Tl}$ concentration in lettuce plants was similar to that of Bunzl et al. [68] in plants grown in noncontaminated soils, to indicate that lettuce plants are sensitive to $\mathrm{Tl}$ and do not take easily it up, even when its bioavailability is enhanced in the rhizosphere soil. White campion showed the highest $\mathrm{Tl}$ concentration in shoots as compared to the other studied plants and a BAF $>1$ (Table 4, Table 5), which indicates a high Tl accumulation efficiency of this plant. Accordingly, many authors demonstrated that white campion highly accumulates $\mathrm{Tl}$ in its shoots and can show a Tl BAF up to 11 in soils polluted by anthropogenic $\mathrm{Tl}[27,28,69]$. Our findings thus reveals that white campion can take up and accumulate high $\mathrm{Tl}$ concentrations also in soil where $\mathrm{Tl}$ derives from geological sources.

Zinc concentration in lettuce shoots at the third harvest was higher than reference ranges proposed by Kabata-Pendias [12] for food plants (Table 3). The concentrations of $\mathrm{Zn}$ found in our lettuces were analogous to those observed by Antoniadis et al. [19], who grew the plants in soils showing a similar $\mathrm{Zn}$ mobility. $\mathrm{Zn}$ is an essential micronutrient for plants, moreover it is generally quite mobile and bioavailable in the soil $[67,70]$, hence it is conceivable that plants as lettuce can take up and assimilate high concentrations of this metal from the rhizosphere soil.

In general, PTE concentrations in plant shoots tended to increase in the second and third harvests, except for $\mathrm{Tl}$ in lettuce and white campion (Table 3). The promptly bioavailable fractions of $\mathrm{Cu}$ and $\mathrm{Tl}$ in the soil raised from the time $\mathrm{T} 0$ to the end of the experiment, after plant growth and three consecutive harvests, while on the contrary those of $\mathrm{Cd}$ and $\mathrm{Zn}$ decreased over time (Table 2). This behaviour for $\mathrm{Cd}$ and $\mathrm{Zn}$ suggested that the uptake of the promptly bioavailable fractions of these two metals by plants was intense and faster than the progressive conversion of less bioavailable pools into easily available pools in the soil [71]. On the contrary, the promptly bioavailable contents of $\mathrm{Cu}$ and $\mathrm{Tl}$ in the soil were enhanced over time probably because the less available pools were easily turned into easily available pools by root exudates and soil biota [72].

These trends were also ascertained by correlating the metal promptly bioavailable contents in the soil and PTE concentrations in plants (Table 6).

A statistically significant positive soil vs plant correlation was observed for $\mathrm{Cu}$ and $\mathrm{Tl}$ (only for perennial wall rocket), while a statistically significant negative soil vs plant correlation was noticed for $\mathrm{Zn}$ (Table 6). A similar positive correlation between $\mathrm{NH}_{4} \mathrm{NO}_{3}$-extractable fraction in soil and total content in plant was reported for $\mathrm{Cu}$ and $\mathrm{Tl}$ in previous studies, to indicate that the fluctuations of promptly bioavailable contents of metals in the soil are generally related to the amounts taken up and assimilated by the plants $[73,74]$. 
Table 6. Pearson correlation coefficients showing the relationship between the promptly available content of PTEs in soil and concentration of PTEs in aerial plant biomass.

\begin{tabular}{|c|c|c|c|c|c|}
\hline & & \multicolumn{4}{|c|}{ Soil } \\
\hline & & $\mathrm{Cu}$ & $\mathrm{Pb}$ & $\mathrm{Tl}$ & $\mathrm{Zn}$ \\
\hline \multirow{4}{*}{ L. sativa } & $\mathrm{Cu}$ & 0.741 * & & \multirow{4}{*}{0.088} & \\
\hline & $\mathrm{Pb}$ & & -0.391 & & \\
\hline & $\mathrm{Tl}$ & & & & \\
\hline & $\mathrm{Zn}$ & & & & -0.873 * \\
\hline \multirow{4}{*}{ D. tenuifolia } & $\mathrm{Cu}$ & $0.974^{*}$ & & \multirow{4}{*}{0.958 * } & \\
\hline & $\mathrm{Pb}$ & & -0.680 & & \\
\hline & $\mathrm{Tl}$ & & & & \\
\hline & $\mathrm{Zn}$ & & & & -0.738 * \\
\hline \multirow{4}{*}{ S. latifolia } & $\mathrm{Cu}$ & 0.944 * & & \multirow{4}{*}{-0.658} & \\
\hline & $\mathrm{Pb}$ & & 0.187 & & \\
\hline & $\mathrm{Tl}$ & & & & \\
\hline & $\mathrm{Zn}$ & & & & -0.957 * \\
\hline
\end{tabular}

* Correlation is significant at the 0.05 level (two-tailed).

\subsection{Health Risk Assessment}

The risk of non-carcinogenic toxicity to different age classes of humans due to dietary intake of PTEs from the studied crops are shown in Table 7.

Table 7. Hazard quotients (HQ) and hazard indexes (HI) through dietary intake of L. sativa, D. tenuifolia and S. latifolia by consumers.

\begin{tabular}{|c|c|c|c|c|c|c|c|}
\hline \multirow[b]{2}{*}{ Plant } & \multicolumn{7}{|c|}{ HQ } \\
\hline & Age group & $\mathrm{Cd}$ & $\mathrm{Cu}$ & $\mathrm{Pb}$ & $\mathrm{Tl}$ & $\mathrm{Zn}$ & HI \\
\hline \multirow{4}{*}{ L. Sativa } & Children & $3.14 \times 10^{-2}$ & $2.71 \times 10^{-2}$ & $1.27 \times 10^{-2}$ & $4.66 \times 10^{-1}$ & $1.17 \times 10^{-2}$ & $5.49 \times 10^{-1}$ \\
\hline & Teenagers & $2.33 \times 10^{-2}$ & $2.01 \times 10^{-2}$ & $9.42 \times 10^{-3}$ & $3.45 \times 10^{-1}$ & $8.65 \times 10^{-3}$ & $4.06 \times 10^{-1}$ \\
\hline & Adults & $2.54 \times 10^{-2}$ & $2.19 \times 10^{-2}$ & $1.03 \times 10^{-2}$ & $3.76 \times 10^{-1}$ & $9.43 \times 10^{-3}$ & $4.43 \times 10^{-1}$ \\
\hline & Elderly & $2.53 \times 10^{-2}$ & $2.18 \times 10^{-2}$ & $1.02 \times 10^{-2}$ & $3.75 \times 10^{-1}$ & $9.41 \times 10^{-3}$ & $4.42 \times 10^{-1}$ \\
\hline \multirow{4}{*}{ S. latifolia } & Children & $1.34 \times 10^{-1}$ & $1.48 \times 10^{-1}$ & $5.51 \times 10^{-2}$ & $7.46 \times 10^{1}$ & $1.98 \times 10^{-2}$ & $7.49 \times 10^{1}$ \\
\hline & Teenagers & $9.70 \times 10^{-2}$ & $1.07 \times 10^{-1}$ & $3.98 \times 10^{-2}$ & $5.39 \times 10^{1}$ & $1.43 \times 10^{-2}$ & $5.41 \times 10^{1}$ \\
\hline & Adults & $8.48 \times 10^{-2}$ & $9.38 \times 10^{-2}$ & $3.48 \times 10^{-2}$ & $4.71 \times 10^{1}$ & $1.25 \times 10^{-2}$ & $4.73 \times 10^{1}$ \\
\hline & Elderly & $6.24 \times 10^{-2}$ & $6.90 \times 10^{-2}$ & $2.56 \times 10^{-2}$ & $3.47 \times 10^{1}$ & $9.21 \times 10^{-3}$ & $3.48 \times 10^{1}$ \\
\hline \multirow{4}{*}{$\begin{array}{c}D . \\
\text { tenuifolia }\end{array}$} & Children & $7.36 \times 10^{-3}$ & $1.07 \times 10^{-2}$ & $3.81 \times 10^{-3}$ & $3.95 \times 10^{-1}$ & $3.43 \times 10^{-3}$ & $4.20 \times 10^{-1}$ \\
\hline & Teenagers & $4.72 \times 10^{-3}$ & $6.87 \times 10^{-3}$ & $2.44 \times 10^{-3}$ & $2.54 \times 10^{-1}$ & $2.20 \times 10^{-3}$ & $2.70 \times 10^{-1}$ \\
\hline & Adults & $4.98 \times 10^{-3}$ & $7.24 \times 10^{-3}$ & $2.58 \times 10^{-3}$ & $2.67 \times 10^{-1}$ & $2.32 \times 10^{-3}$ & $2.84 \times 10^{-1}$ \\
\hline & Elderly & $6.45 \times 10^{-3}$ & $9.38 \times 10^{-3}$ & $3.33 \times 10^{-3}$ & $3.46 \times 10^{-1}$ & $3.00 \times 10^{-3}$ & $3.68 \times 10^{-1}$ \\
\hline
\end{tabular}

Thallium was the element with the highest risk for human health, representing the $85 \%, 94 \%$ and $99 \%$ of the hazard index (HI), respectively, for lettuce, perennial wall rocket and white campion. This is a consequence of both high $\mathrm{Tl}$ concentration in plants and the lowest oral reference dose of $\mathrm{Tl}$ ( $\left.0.001 \mathrm{mg} \mathrm{kg}^{-1}\right)$, if compared to the other PTEs [75]. Thallium HQ was above 1 only for white campion ranging from 34.7 for elderly to 74.6 for children (Table 7) indicating a significant non-carcinogenic risk for human health. HQs found for Tl in our pot trial were similar to those of other studies in Tl-rich soils, this means that the possible intake of white campion may pose a serious risk for human health if grown in a soil rich in $\mathrm{Tl}$ of geogenic nature. In particular, Wang et al. [76] reported HQ up to 50 for children and 30 for adults in food plants grown on soils with total Tl concentrations up to $177 \mathrm{mg} \mathrm{kg}^{-1}$. Similarly, Huang et al. [77], reported Tl HQ of 57.6 in soil with Tl concentration of 
$6.3 \mathrm{mg} \mathrm{kg}^{-1}$. The noncarcinogenic hazard indexes (HI) related to the intake of lettuce and perennial wall rocket were below the safe level $(<1)$. On the contrary, the HI for white campion was above 1 , ranging from 34.8 for elderly to 74.9 for children (Table 7), thus indicating a potential noncarcinogenic risk due to the ingestion of this plant. Results of the health risk assessment for white campion also showed that children are at higher risk to PTE exposure than adults and elderly. This is essentially due to the high food ingestion of children in proportion to their body size and to the low ability to metabolize, detoxify and excrete toxins; in other words, a not-dangerous dose for an adult may be dangerous for a child $[50,78]$.

Health risk assessment was also calculated for farm workers based on two exposure pathways: direct soil ingestion and soil dermal contact (Table 8).

Table 8. Hazard quotients (HQ) and hazard indexes (HI) through soil ingestion and dermal contact by farm workers.

\begin{tabular}{ccccccc}
\hline \multicolumn{7}{c}{ HQ } \\
\hline Exposure Pathway & $\mathbf{C d}$ & $\mathbf{C u}$ & $\mathbf{P b}$ & $\mathbf{T l}$ & $\mathbf{Z n}$ & HI \\
\hline Ingestion & $4.31 \times 10^{-4}$ & $4.38 \times 10^{-3}$ & $5.04 \times 10^{-2}$ & $2.93 \times 10^{-1}$ & $6.38 \times 10^{-4}$ & $3.49 \times 10^{-1}$ \\
Dermal & $1.52 \times 10^{-5}$ & $1.93 \times 10^{-5}$ & $2.22 \times 10^{-4}$ & $2.59 \times 10^{-4}$ & $2.81 \times 10^{-6}$ & $5.18 \times 10^{-4}$ \\
\hline
\end{tabular}

The risk linked to each PTE (HQ) and the total risk (HI) were below 1 for both the exposure pathways, thus there is no risk for farmers working on the studied farmland. The low risk is mostly related to the low exposure frequency of farm workers that in turn limits the exposure to PTEs [79]. As for dietary risk assessment, $\mathrm{Tl}$ was the most risky element for soil ingestion and dermal contact as well, representing $84 \%$ and $50 \%$, respectively, of the hazard index (HI) (Table 8 ). The high toxicity of this element, showing a very low oral and dermal $\operatorname{RfD}\left(0.001 \mu \mathrm{g} \mathrm{kg}^{-1}\right)$, is the main responsible of this prominent contribution to the overall risk $[47,48,75]$.

Only the carcinogenic risk of $\mathrm{Pb}$ was calculated, since the carcinogenic slope factors for $\mathrm{Cd}, \mathrm{Cu}, \mathrm{Tl}$ and $\mathrm{Zn}$ are not available [47]. The cancer risk of $\mathrm{Pb}$ through dietary intake of the three plants was always lower than $1 \times 10^{-6}$, thus resulting negligible for all the classes of humans (Figure 1 [51]). Similarly, cancer risk of $\mathrm{Pb}$ for farm workers through ingestion and dermal contact of soil were insignificant, with values of $9.2 \times 10^{-7}$ and $4.1 \times 10^{-9}$, respectively [51].

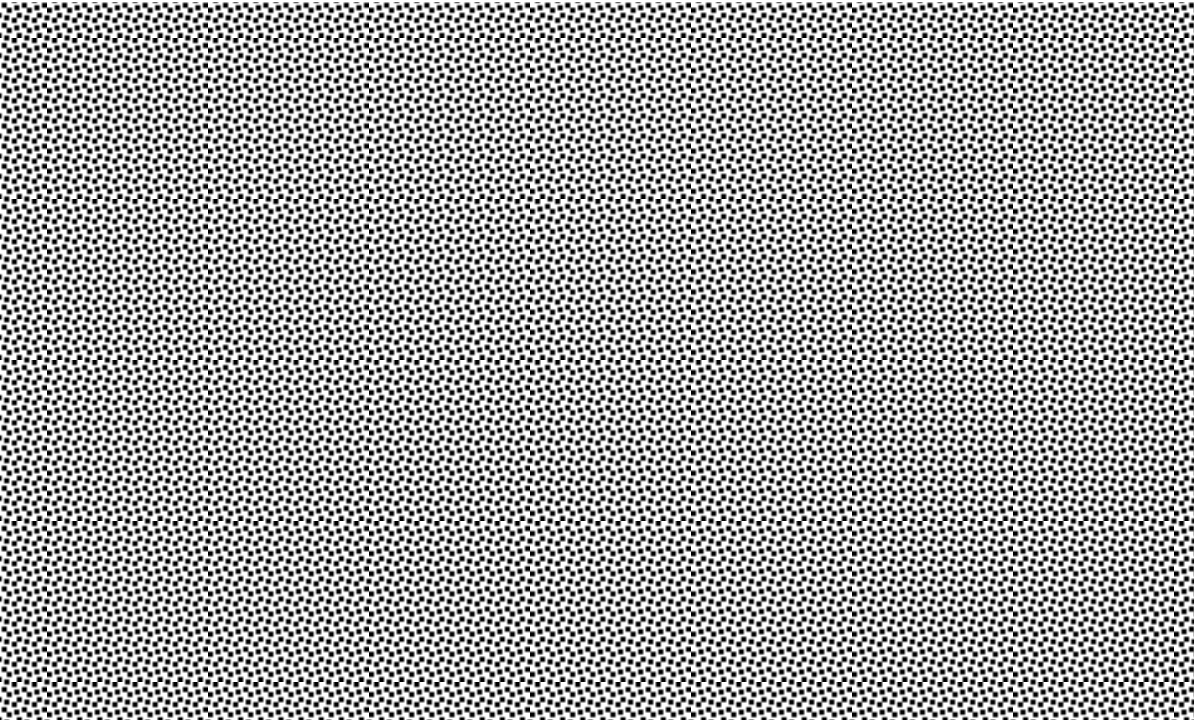

(a)

Figure 1. Cont. 


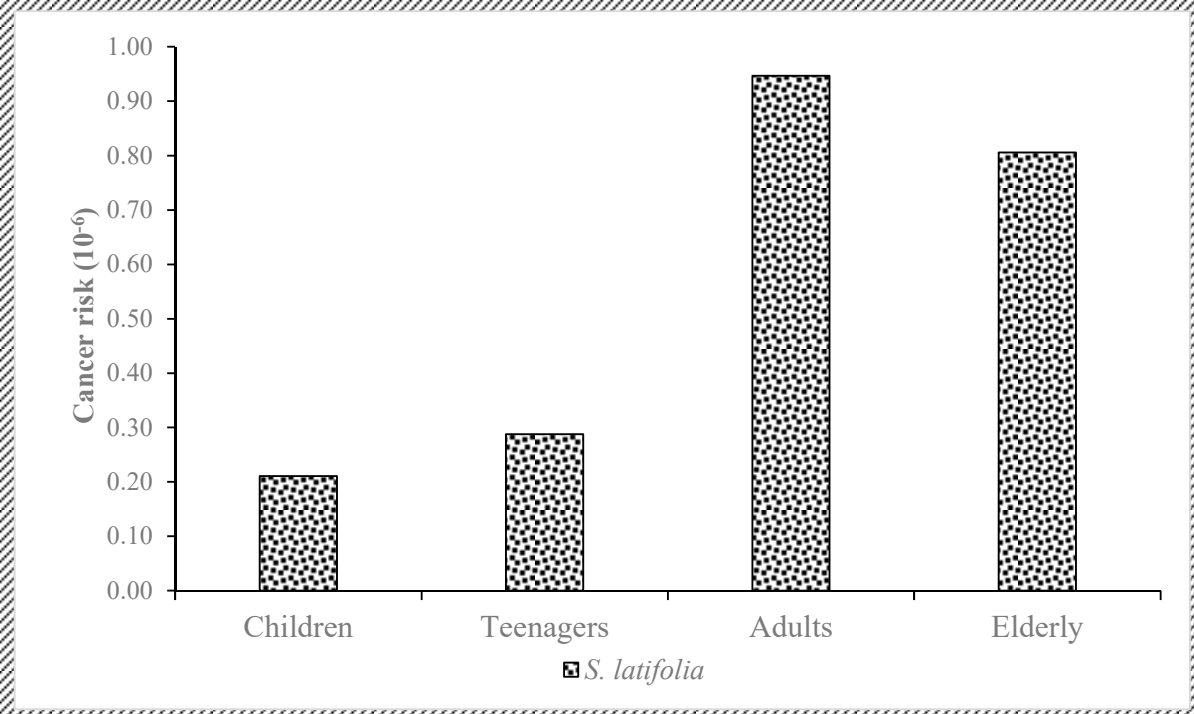

(b)

Figure 1. Cancer risk $(\mathrm{CR})$ of $\mathrm{Pb}$ through dietary intake of L. Sativa and D. tenuifolia (a) and of S. latifolia (b).

\section{Conclusions}

This study aimed to assess the potential risks for human health deriving from the agriculture use of a soil located in the volcanic metropolitan area of Naples (southern Italy) and showing pseudototal contents of $\mathrm{Tl}$ and $\mathrm{Pb}$ of geogenic nature above screening values for agricultural soils. The soil extraction by $1 \mathrm{M} \mathrm{NH}_{4} \mathrm{NO}_{3}$ basically revealed that all the PTEs, including $\mathrm{Tl}$ and $\mathrm{Pb}$, were poorly bioavailable in the soil. This behaviour is essentially due to the geogenic nature of all the PTEs in the soil, which are likely occluded or interlayered in the soil mineral lattice. Nevertheless, repeated croppings of $L$. sativa L., D. tenuifolia L. and S. latifolia Poir. raised the promptly bioavailable content of $\mathrm{Cu}$ and $\mathrm{Tl}$ in the soil above internationally recognized trigger values and accumulated relatively high concentrations of $\mathrm{Cd}, \mathrm{Cu}, \mathrm{Tl}$ and $\mathrm{Zn}$ in shoots. However, acceptable risks $(\mathrm{HI}<1)$ were found, arising from the dietary intake of lettuce and perennial wall rocket, soil ingestion and dermal contact by farm workers. Only the ingestion of white campion might lead to significant health risks, in particular for children. No carcinogenic risks due to $\mathrm{Pb}$ exposure were found.

The findings of this work demand the proper management of soil used for agricultural purposes, in order to minimise the possible transfer of $\mathrm{Tl}$ and other PTEs to food crops and hence to consumers eating vegetables grown on site or farmers working out in the field. It is evident that the selection of food crops is crucial to cultivate on site, since different plant species can differently affect the mobility and bioavailability of $\mathrm{Tl}$ and other PTEs in the soil by their own rhizodepositions, taking up and accumulating the metals in the edible portions to a different extent.

Supplementary Materials: The following are available online at http://www.mdpi.com/2073-4395/10/6/890/s1, Figure S1: Map of the studied site and sampling points (top) in the rural area of Afragola (Naples, Campania, Italy) and greenhouse pot experiment with L. sativa, D. tenuifolia and S. latifolia. Table S1: Oral reference doses (RfDo) related to non-carcinogenic health risk and oral slope factor (SFo; unitless) related to carcinogenic health risk. Table S2: Reference parameters used in health risk assessment on the consumption of vegetables by children, teenagers, adults and elderly. Table S3: Reference parameters used in health risk assessment on the ingestion and dermal contact of soil by farm workers. Table S4: Pseudo-total content of PTEs $\left(\mathrm{mg} \mathrm{kg}^{-1}\right)$ in the eight discrete soil samples collected from the studied agricultural soil. Table S5: PTEs concentrations ( $\mathrm{mg} \mathrm{kg}^{-1} \mathrm{f}$. w.) in shoots of L. sativa, D. tenuifolia and S. latifolia from the first, second and third harvest.

Author Contributions: Conceptualization, M.F., D.V., N.F. and P.A.; methodology, D.V. and L.G.D.; formal analysis, D.V. and A.G.C.; investigation, D.V. and L.G.D.; writing-original draft preparation, D.V. and A.G.C.; writing-review and editing, M.F., N.F. and P.A.; supervision, A.G.C. and M.F.; project administration, M.F.; funding acquisition, M.F. All authors have read and agreed to the published version of the manuscript. 
Funding: This research was funded by EC LIFE11/ENV/IT 275 Ecoremed and Italian MIUR PRIN2017BHH84R.

Acknowledgments: We would like to thank Eugenio Cozzolino and Vincenzo Cenvinzo for their support in crop management and sampling.

Conflicts of Interest: The authors declare no conflict of interest. The funders had no role in the design of the study; in the collection, analyses, or interpretation of data; in the writing of the manuscript, or in the decision to publish the results.

\section{References}

1. Peter, A.L.J.; Viraraghavan, T. Thallium: A review of public health and environmental concerns. Environ. Int. 2005, 31, 493-501. [CrossRef] [PubMed]

2. USEPA. Toxicological review of thallium and compounds. In Support of Summary Information on the Integrated Risk Information System (IRIS); Report no. EPA/635/R-08/001F; U.S. Environmental Protection Agency: Washington, DC, USA, 2009.

3. Zhao, G.; Ding, M.; Zhang, B.; Lv, W.; Yin, H.; Zhang, L.; Ying, Z.; Zhang, Q. Clinical manifestations and management of acute thallium poisoning. Eur. Neurol. 2008, 60, 292-297. [CrossRef] [PubMed]

4. Tsai, Y.; Huang, C.; Kuo, H.; Wang, H.; Shen, W.; Shih, T.; Chu, N. Central nervous system effects in acute thallium poisoning. Neuro. Toxicol. 2006, 27, 291-295. [CrossRef]

5. Pelclová, D.; Urban, P.; Ridzoň, P.; Šenholdová, Z.; Lukáš, E.; Diblík, P.; Lacina, L. Two-year follow-up of two patients after severe thallium intoxication. Hum. Exp. Toxicol. 2009, 28, 263-272. [CrossRef] [PubMed]

6. USEPA. Priority Pollutant List; United States Environmental Protection Agency: Washington, DC, USA, 2014.

7. Cobelo-García, A.; Filella, M.; Croot, P.; Frazzoli, C.; Du Laing, G.; Ospina-Alvarez, N.; Rauch, S.; Salaun, P.; Schäfer, J.; Zimmermann, S.; et al. COST action TD1407: Network on technology-critical elements (NOTICE)-From environmental processes to human health threats. Environ. Sci. Pollut. Res. 2015, 22, 15188-15194. [CrossRef]

8. D'Orazio, M.; Campanella, B.; Bramanti, E.; Ghezzi, L.; Onor, M.; Vianello, G.; Vittori Antisari, L.; Petrini, R. Thallium pollution in water, soils and plants from a past-mining site of Tuscany: Sources, transfer processes and toxicity. J. Geochem. Explor. 2020, 209, 106434. [CrossRef]

9. Karbowska, B. Presence of thallium in the environment: Sources of contaminations, distribution and monitoring methods. Environ. Monit. Assess. 2016, 188, 640. [CrossRef]

10. Viraraghavan, T.; Srinivasan, A. Thallium: Environmental pollution and health effects. In Encyclopedia of Environmental Health; Nriagu, J.O., Ed.; Elsevier: Burlington, MA, USA, 2011; pp. 325-333.

11. Belzile, N.; Chen, Y.W. Thallium in the environment: A critical review focused on natural waters, soils, sediments and airborne particles. Appl. Geochem. 2017, 84, 218-243. [CrossRef]

12. Kabata-Pendias, A. Trace Elements in Soils and Plants; CRC Press Taylor \& Francis Group: Boca Raton, FL, USA, 2011.

13. Liu, J.; Wei, X.; Zhou, Y.; Tsang, D.C.W.; Bao, Z.; Yin, M.; Lippold, H.; Yuan, W.; Wang, J.; Feng, Y.; et al. Thallium contamination, health risk assessment and source apportionment in common vegetables. Sci. Total Environ. 2019, 703, 135547. [CrossRef]

14. Liu, J.; Li, N.; Zhang, W.; Wei, X.; Tsang, D.C.W.; Sun, Y.; Luo, X.; Bao, Z.; Zheng, W.; Wang, J.; et al. Thallium contamination in farmlands and common vegetables in a pyritemining city and potential health risks. Environ. Pollut. 2019, 248, 906-915. [CrossRef]

15. Tremel, A.; Masson, P.; Garraud, H.; Donard, O.F.X.; Baize, D.; Mench, M. Thallium in French agrosystems-II. concentration of thallium in field-grown rape and some other plant species. Environ. Pollut. 1997, 97, 161-168. [CrossRef]

16. Grösslovà, Z.; Vanèk, A.; Obornà, V.; Mihaljevìc, M.; Ettler, V.; Trubač, J.; Drahota, P.; Penízek, V.; Pavlù, L.; Sracek, O.; et al. Thallium contamination of desert soil in Namibia: Chemical, mineralogical and isotopic insights. Environ. Pollut. 2018, 239, 272-280. [CrossRef] [PubMed]

17. Duri, L.G.; Fiorentino, N.; Cozzolino, E.; Ottaiano, L.; Agrelli, D.; Fagnano, M. Bioassays for evaluation of sanitary risks from food crops cultivated in potentially contaminated sites. Ital. J. Agron. 2018, 13 (Suppl. 1), $45-52$.

18. LaCoste, C.; Robinson, B.; Brooks, R. Uptake of thallium by vegetables: Its significance for human health, phytoremediation, and phytomining. J. Plant Nutr. 2001, 24, 1205-1215. [CrossRef] 
19. Antoniadis, V.; Shaheen, S.M.; Boersch, J.; Frohne, T.; Du Laing, G.; Rinklebe, J. Bioavailability and risk assessment of potentially toxic elements in garden edible vegetables and soils around a highly contaminated former mining area in Germany. J. Environ. Manag. 2017, 186, 192-200. [CrossRef] [PubMed]

20. Pignatti, S.; Guarino, R.; La Rosa, M. Flora d'Italia; Edagricole: Bologna, Italy, 2017.

21. Caruso, G.; Parrella, G.; Giorgini, M.; Nicoletti, R. Crop systems, quality and protection of Diplotaxis tenuifolia. Agriculture 2018, 8, 55. [CrossRef]

22. Grabner, B.; Ribaric-Lasnik, C.; Romih, N.; Pfeifhofer, H.W.; Batic, F. Bioaccumulation capacity for Pb, Cd and $\mathrm{Zn}$ from polluted soil in selected species of the Brassicaceae family growing in different vegetation types. Phyton 2011, 50, 287-300.

23. Alarcon, R.; Ortiz, L.T.; Garcia, P. Nutrient and fatty acid composition of wild edible bladder campion populations [Silene vulgaris (Moench.) Garcke]. Int. J. Food Sci. Technol. 2006, 41, 1239-1242. [CrossRef]

24. Tardío, J.; De-Santayana, M.P.; Morales, R. Ethnobotanical review of wild edible plants in Spain. Bot. J. Linn. Soc. 2006, 152, 27-71. [CrossRef]

25. Luczaj, L.; Dolina, K. A hundred years of change in wild vegetable use in southern Herzegovina. J. Ethnopharmacol. 2015, 166, 297-304. [CrossRef]

26. Guarrera, P.M.; Savo, V. Wild food plants used in traditional vegetable mixtures in Italy. J. Ethnopharmacol. 2016, 185, 202-234. [CrossRef] [PubMed]

27. Escarrè, J.; Lefebvre, C.; Raboyeau, S.; Dossantos, A.; Gruber, W.; Cleyet Marel, J.C.; Frerot, H.; Noret, N.; Mahieu, S.; Collin, C.; et al. Heavy metal concentration survey in soils and plants of the les Malines mining district (Southern France): Implications for soil restoration. Water Air Soil Pollut. 2011, 216, 485-504. [CrossRef]

28. Visconti, D.; Fiorentino, N.; Stinca, A.; Di Mola, I.; Fagnano, M. Use of the native vascular flora for risk assessment and management of an industrial contaminated soil. Ital. J. Agron. 2018, 13, 23-33.

29. Visconti, D.; Fiorentino, N.; Caporale, A.G.; Stinca, A.; Adamo, P.; Motti, R.; Fagnano, M. Analysis of native vegetation for detailed characterization of a soil contaminated by tannery waste. Environ. Pollut. 2019, 252, 1599-1608. [CrossRef] [PubMed]

30. Khelifi, F.; Melki, A.; Hamed, Y.; Adamo, P.; Caporale, A.G. Environmental and human health risk assessment of potentially toxic elements in soil, sediments and ore-processing wastes from a mining area of southwestern Tunisia. Environ. Geochem. Health 2019. [CrossRef] [PubMed]

31. Adamo, P.; Agrelli, D.; Zampella, M. Chemical speciation to assess bioavailability, bioaccessibility and geochemical forms of potentially toxic metals (PTMs) in polluted soils. In Environmental Geochemistry, Site Characterization, Data Analysis and Case Histories, 2nd ed.; De Vivo, B., Belkin, H.E., Lima, A., Eds.; Elsevier: Amsterdam, The Netherlands, 2018; pp. 153-194.

32. Violante, A.; Caporale, A.G. Biogeochemical processes at soil-root interface. J. Soil Sci. Plant Nutr. 2015, 15, 422-448. [CrossRef]

33. BBodSchV. Bodenschutz- und Altlastenverordnung (Federal Soil Protection and Contaminated Sites Ordinance). 12 July 1999. Germany. Available online: https://www.gesetze-im-internet.de/bbodschv/ BBodSchV.pdf (accessed on 21 June 2020).

34. ASP. Act No. 220/2004 Coll. on the Protection and Use of the Agricultural Soil; The National Council of the Slovak Republic: Bratislava, Slovakia, 2004.

35. Caporale, A.G.; Adamo, P.; Capozzi, F.; Langella, G.; Terribile, F.; Vingiani, S. Monitoring metal pollution in soils using portable-XRF and conventional laboratory-based techniques: Evaluation of the performance and limitations according to metal properties and sources. Sci. Total Environ. 2018, 643, 516-526. [CrossRef]

36. Di Gennaro, A.; Aronne, G.; De Mascellis, R.; Vingiani, S.; Sarnataro, M.; Abalsamo, P.; Cona, F.; Vitelli, L.; Arpaia, G. I sistemi di Terre Della Campania. Monografia e Carta 1:250.000, con Legenda; Società Elaborazioni Cartografiche: Firenze, Italy, 2002; p. 63.

37. Vingiani, S.; Buonanno, M.; Coraggio, S.; D’Antonio, A.; De Mascellis, R.; Di Gennaro, A.; Iamarino, M.; Langella, G.; Manna, P.; Moretti, P.; et al. Soils of the Aversa plain (southern Italy). J. Maps 2018, 14, 312-320. [CrossRef]

38. Ellili, A.; Rabier, J.; Prudent, P.; Salducci, M.D.; Heckenroth, A.; Lachaal, M.; Laffont-Schwob, I. Decision-making criteria for plant-species selection for phytostabilization: Issues of biodiversity and functionality. J. Environ. Manag. 2017, 201, 215-226. [CrossRef] 
39. Commission Regulation (EC) No 1881/2006 of 19 December 2006-Setting Maximum Levels for Certain Contaminants in Foodstuffs. Available online: https://eur-lex.europa.eu/legal-content/EN/ALL/?uri=celex: 32006R1881 (accessed on 16 May 2020).

40. Walkley, A.; Black, I.A. An examination of Degtjareff method for determining soil organic matter and a proposed modification of the chromic acid titration method. Soil Sci. 1934, 37, 29-37. [CrossRef]

41. ISO 12914. Soil Quality-Microwave-Assisted Extraction of the Aqua Regia Soluble Fraction for the Determination of Elements; International Organization for Standardization: Geneva, Switzerland, 2012.

42. DIN 19730. Bodenbeschaffenheit-Extraktion von Spurenelementen mit Ammoniumnitratlösung; Beuth Verlag: Berlin, Germany, 1997.

43. Italian Ministerial Decree 46. Collection of Laws No. 220 of 10 March 2004 on the Protection and Use of Agricultural Land. Available online: https://www.gazzettaufficiale.it/eli/id/2019/06/07/19G00052/sg (accessed on 21 June 2020).

44. USEPA. Risk Assessment Guidance for Superfund vol. I: Human Health Evaluation Manual Supplemental Guidance: Standard Default Exposure Factors, Interim Final, OSWER Directive 9285.6-03; Office of Emergency and Remedial Response, US Environmental Protection Agency: Washington, DC, USA, 1991.

45. USEPA. Risk Assessment Guidance for Superfund, Human Health Evaluation Manual, Part A, vol. 1; Report no. EPA/540/1-89/002; Office of Emergency and Remedial Response, US Environmental Protection Agency: Washington, DC, USA, 1989.

46. USEPA. Handbook for Non-Cancer Health Effects Evaluation; US Environmental Protection Agency: Washington, DC, USA, 2000.

47. USEPA. Toxicity and Chemical/Physical Properties for Regional Screening Level (RSL) of Chemical Contaminants at Superfund Sites. Available online: http://www.epa.gov/region9/superfund/prg/tablegeneric-tables (accessed on 16 May 2020).

48. USEPA. Risk Assessment Guidance for Superfund, Volume I: Human Health Evaluation Manual. Part E, Supplemental Guidance for Dermal Risk Assessment. Final [EPA/540/R/99/005]; Office of Superfund Remediation and Technology Innovation, US Environmental Protection Agency: Washington, DC, USA, 2004.

49. USEPA. Exposure Factors Handbook [EPA/600/R-09/052F]; US Environmental Protection Agency: Washington, DC, USA, 2011.

50. Lian, M.; Wang, J.; Sun, L.; Xu, Z.; Tang, J.; Yan, J.; Zeng, X. Profiles and potential health risks of heavy metals in soil and crops from the watershed of Xi River in Northeast China. Ecotoxicol. Environ. Saf. 2019, 169, 442-448. [CrossRef] [PubMed]

51. USEPA. Supplemental Guidance for Developing Soil Screening Levels for Superfund Sites, [OSWER 9355.4-24]; Office of Solid Waste and Emergency Response, US Environmental Protection Agency: Washington, DC, USA, 2002.

52. Cicchella, D.; De Vivo, B.; Lima, A. Background and baseline concentration values of harmful elements in the volcanic soils of metropolitan and Provincial areas of Napoli (Italy). Geochem. Explor. Environ. Anal. 2005, 5, 29-40. [CrossRef]

53. De Vivo, B.; Lima, A.; Albanese, S.; Rezza, C.; Civitillo, D.; Minolfi, G.; Zuzolo, D. Atlante Geochimico-Ambientale dei Suoli Della Campania-Environmental Geochemical Atlas of Campania Soils; Aracne: Ariccia, Italy, 2016; p. 364.

54. Carlon, C. Derivation Methods of Soil Screening Values in Europe. A Review and Evaluation of National Procedures towards Harmonization, EUR 22805-EN.; European Commission, Joint Research Centre, ISPRA: Rome, Italy, 2007; p. 306.

55. Caporale, A.G.; Violante, A. Chemical processes affecting the mobility of heavy metals and metalloids in soil environments. Curr. Pollut. Rep. 2016, 2, 15-27. [CrossRef]

56. Rocco, C.; Agrelli, D.; Tafuro, M.; Caporale, A.G.; Adamo, P. Assessing the bioavailability of potentially toxic elements in soil: A proposed approach. Ital. J. Agron. 2018, 13, 16-22.

57. Wedepohl, K.H. The composition of the continental crust. Geochim. Cosmochim. Acta 1995, 59, 1217-1232. [CrossRef]

58. Jacobson, A.R.; McBride, M.B.; Baveye, P.; Steenhuis, T.S. Environmental factors determining the trace-level sorption of silver and thallium to soils. Sci. Total Environ. 2005, 345, 191-205. [CrossRef]

59. Pavoni, E.; Petranich, E.; Adami, G.; Baracchini, E.; Crosera, M.; Emili, A.; Lenaz, D.; Higueras, P.; Covelli, S. Bioaccumulation of thallium and other trace metals in Biscutella laevigata nearby a decommisioned zinc-lead mine (Northeastern Italian Alps). J. Environ. Manag. 2017, 186, 214-224. [CrossRef] 
60. Bravin, M.N.; Garnier, C.; Lenoble, V.; Gèrard, F.; Dudal, Y.; Hinsinger, P. Root-induced changes in $\mathrm{pH}$ and dissolved organic matter binding capacity affect copper dynamic speciation in the rhizosphere. Geochim. Cosmochim. Acta 2012, 84, 256-268. [CrossRef]

61. Visconti, D.; Fiorentino, N.; Cozzolino, E.; Woo, S.L.; Fagnano, M.; Rouphael, Y. Can trichoderma-based biostimulants optimize $\mathrm{N}$ use efficiency and stimulate growth of leafy vegetables in greenhouse intensive cropping systems? Agronomy 2019, 10, 121. [CrossRef]

62. Simko, I. Genetic variation in response to N, P, or K deprivation in baby leaf lettuce. Horticulturae 2020, 6, 15. [CrossRef]

63. Li, X.Y.; Li, Z.G.; Lin, C.J.; Bi, X.Y.; Liu, J.L.; Feng, X.B.; Zhang, H.; Chen, J.; Wu, T.T. Health risks of heavy metal exposure through vegetable consumption near a large-scale $\mathrm{Pb} / \mathrm{Zn}$ smelter in central China. Ecotoxicol. Environ. Saf. 2018, 161, 99-110. [CrossRef] [PubMed]

64. Menzies, N.W.; Donn, M.J.; Kopittke, P.M. Evaluation of extractants for the estimation of the phytoavailable trace metals in soils. Environ. Pollut. 2007, 145, 121-130. [CrossRef] [PubMed]

65. Fang, H.W.; Li, W.S.; Tu, S.X.; Ding, Y.Z.; Wang, R.G.; Rensing, C.; Li, Y.P.; Feng, R.W. Differences in cadmium absorption by 71 leaf vegetable varieties from different families and genera and their health risk assessment. Ecotoxicol. Environ. Saf. 2019, 184, 109593. [CrossRef] [PubMed]

66. Lyubenova, L.; Kuhn, A.J.; Höltkemeier, A.; Schröder, P. Root exudation pattern of Typha latifolia L. plants after copper exposure. Plant Soil 2013, 370, 187-195. [CrossRef]

67. Franca, F.C.S.S.; Albuuerque, A.M.A.; Almeida, A.C.; Silveira, P.B.; Filho, C.A.; Hazin, C.A.; Honorato, E.V. Heavy metals deposited in the culture of lettuce (Lactuca sativa L.) by the influence of vehicular traffic in Pernambuco Brazil. Food Chem. 2017, 215, 171-176. [CrossRef]

68. Bunzl, K.; Trautmannsheimer, M.; Schramel, P.; Reifenhauser, W. Availability of arsenic, copper, lead, thallium, and zinc to various vegetables grown in slag-contaminated soils. J. Environ. Qual. 2001, 30, 934-939. [CrossRef]

69. Marchiol, L.; Fellet, G.; Boscutti, F.; Montella, C.; Mozzi, R.; Guarino, C. Gentle remediation at the former "Pertusola Sud" zinc smelter: Evaluation of native species for phytoremediation purposes. Ecol. Eng. 2013, 53, 343-353. [CrossRef]

70. Yang, Q.W.; Xu, Y.; Liu, S.J.; He, J.F.; Long, F.Y. Concentration and potential health risk of heavy metals in market vegetables in Chongqing, China. Ecotoxicol. Environ. Saf. 2011, 74, 1664-1669. [CrossRef]

71. Gremion, F.; Chatzinotas, A.; Kaufmann, K.; Von Sigler, W.; Harms, H. Impacts of heavy metal contamination and phytoremediation on a microbial community during a twelve-month microcosm experiment. FEMS Microbiol. Ecol. 2004, 48, 273-283. [CrossRef]

72. Fischerovà, Z.; Tlustos, P.; Szakova, J.; Sichorova, K. A comparison of phytoremediation capability of selected plant species for given trace elements. Environ. Pollut. 2006, 144, 93-100. [CrossRef]

73. Song, J.; Zhao, F.J.; Luo, Y.M.; McGrath, S.P.; Zhang, H. Copper uptake by Elsholtzia splendens and Silene vulgaris and assessment of copper phytoavailability in contaminated soils. Environ. Pollut. 2004, 128, 307-315. [CrossRef] [PubMed]

74. Madejon, P.; Murillo, J.M.; Maranon, T.; Lepp, N.W. Factors affecting accumulation of thallium and other trace elements in two wild Brassicaceae spontaneously growing on soils contaminated by tailings dam waste. Chemosphere 2007, 67, 20-28. [CrossRef] [PubMed]

75. Antoniadis, V.; Golia, E.E.; Liu, Y.-T.; Wang, S.-L.; Shaheen, S.M.; Rinklebe, J. Soil and maize contamination by trace elements and associated health risk assessment in the industrial area of Volos, Greece. Environ. Int. 2019, 124, 79-88. [CrossRef] [PubMed]

76. Wang, C.; Chen, Y.; Liu, J.; Wang, J.; Li, X.; Zhang, Y.; Liu, Y. Health risks of thallium in contaminated arable soils and food crops irrigated with wastewater from sulfuric acid plant in western Guangdong province, China. Ecotoxicol. Environ. Saf. 2013, 90, 76-81. [CrossRef]

77. Huang, X.; Li, N.; Wu, Q.; Long, J.; Luo, D.; Huang, X.; Li, D.; Zhao, D. Fractional distribution of thallium in paddy soil and its bioavailability to rice. Ecotoxicol. Environ. Saf. 2018, 148, 311-317. [CrossRef] 
78. Zeng, X.F.; Wang, Z.W.; Wang, J.; Guo, J.T.; Chen, X.J.; Zhuang, J. Health risk assessment of heavy metals via dietary intake of wheat grown in Tianjin sewage irrigation area. Ecotoxicology 2015, 24, 2115-2124. [CrossRef]

79. Arslan, S.; Aybek, A. Particulate matter exposure in agriculture. In Air Pollution. A Comprehensive Perspective; IntechOpen: London, UK, 2012; Volume 10, pp. 73-104. [CrossRef]

(C) 2020 by the authors. Licensee MDPI, Basel, Switzerland. This article is an open access article distributed under the terms and conditions of the Creative Commons Attribution (CC BY) license (http://creativecommons.org/licenses/by/4.0/). 